\section{Koilocytes are enriched for alkaline-labile sites}

\author{
E.I. Cortés-Gutiérrez, \\ M.I. Dávila-Rodríguez, J.L. Fernández, ${ }^{2}$ \\ C. López-Fernández, ${ }^{3} \mathrm{~J}$. Gosálvez ${ }^{3}$ \\ 'División de Genética, Centro de \\ Investigación Biomédica del Noreste, \\ Instituto Mexicano del Seguro Social, \\ IMSS, Monterrey, México \\ INIBIC - Unidad de Genética, Complejo \\ Hospitalario Universitario Juan Canalejo, \\ As Xubias, La Coruña, Spain \\ ${ }^{3}$ Department of Biology, Genetics Unit, \\ Universidad Autónoma de Madrid, \\ Madrid, Spain
}

\section{Abstract}

This study investigated possible variations in the chromatin structure of koilocytes resulting from human papillomavirus (HPV) infection. Alkaline-labile sites (ALS) were detected with the DNA breakage detection-fluorescence in situ hybridization (DBD-FISH) technique using a whole human genome DNA probe obtained from individuals without koilocytosis. The variable levels of ALS present were measured quantitatively using image analysis after whole-genome DNA hybridization. A significant increase in the number of ALS was observed in koilocytes compared with normal cells. We demonstrated that the presence of ALS could be an indicator of chromatin change in koilocytes caused by HPV infection.

\section{Introduction}

Koilocytes are defined as squamous cells, predominantly superficial and intermediate cells, with a large, well-demarcated, clear perinuclear zone surrounded by a dense peripheral cytoplasmic rim. They provide the most reliable morphological evidence of human papillomavirus (HPV) infection. ${ }^{1,2}$ In the Bethesda System, koilocytes (koilocytosis) and cervical intraepithelial neoplasia (CIN 1) are considered to be low-grade squamous intraepithelial lesions. High-grade squamous intraepithelial lesions include CIN 2 and 3.,

One of the most distinctive features of koilocytes is binucleation and multinucleation (multilobation of a single nucleus) ${ }^{3}$ this can also be seen in reactive processes, including after irradiation, ${ }^{2}$ and is therefore not specific to HPV infection. Nevertheless, it is a common feature in HPV infection, adding weight to the diagnosis especially when it is extensive. A recent study demonstrated that E5 and E6 proteins from HPV cooperate to induce koilocyte formation in human cervical cells in vitro. ${ }^{4}$

DNA breakage detection-fluorescence in situ hybridization (DBD-FISH) is a recently developed technique that allows cell-by-cell detection and quantification of DNA breakage in the whole genome or within specific DNA sequence areas. In this technique, cells are embedded within an inert agarose matrix on a slide and lysed to remove membranes and proteins; the resulting nucleoids are exposed to a controlled denaturation step of alkaline incubation. The alkali transforms DNA breaks into restricted single-stranded DNA (ssDNA) motifs, initiated from the ends of the DNA breaks; these ssDNA motifs can be detected by hybridization with specific or whole-genome fluorescent DNA probes. As the number of DNA breaks increases in a target region, more ssDNA is produced and more probes hybridize, resulting in a more intense FISH signal that can be quantified using image analysis systems.$^{5-7}$ Moreover, the alkaline treatment may break the sugar-phosphate backbone at abasic sites or at sites with deoxyribose damage, transforming these lesions into DNA breaks, also converted into ssDNA. These lesions are traditionally known as alkaline-labile sites (ALS). The DBD-FISH signal obtained in the absence of exogenous DNA-damaging agents reflects the background level of DNA breaks and ALS. The presence of ALS in the genome of a number of cell types indicates that ALS are transient and may vary among cells with conventionally conformed genomes ${ }^{8}$ and that may change in presence of a cell stress ${ }^{9}$ such as a viral infection. This preliminary study demonstrates that an increase in the number of ALS could be an indicator of chromatin change in koilocytosis caused by HPV infection. These data may be seminal for future investigations of mechanisms involved in viral tumorigenesis in humans.

\section{Materials and Methods}

\section{Patients}

We investigated five cervicovaginal swabs obtained by conventional Papanicolaou smear and tissue sections from the same patients obtained from the colposcopic biopsy and simultaneously performed HPV genotyping analysis. All patients were proven to have koilocytosis (binucleation/multinucleation) ${ }^{10}$ or low-grade squamous intraepithelial lesions by Papanicolaou smear, ${ }^{11}$ and CIN 1 by subsequent biopsy. ${ }^{12}$

Five women without cervical lesions and uninfected with HPV were included as a con-
Correspondence: Elva I. Cortés-Gutiérrez, Centro de Investigación Biomédica del Noreste, IMSS, 2 de Abril \# $501 \mathrm{Col}$. Independencia, C.P. 64720 Monterrey, N. L. México. Tel: +52.81 .81904035 - Fax: +52.81 .81904035 . E-mail: elvacortes@cibinmty.net

Key words: koilocytes; binucleated and multinucleated; alkaline-labile sites; DNA breakage detection-fluorescence in situ hybridization (DBD-FISH).

Acknowledgments: the authors thank Sanjuana Guardado Limón for excellent technical assistance. We are grateful to Dr. Angel Zavala Pompa for providing us with the Papanicolaou smears.

Received for publication: 23 February 2010. Accepted for publication: 7 April 2010.

This work is licensed under a Creative Commons Attribution 3.0 License (by-nc 3.0).

(C) Copyright E.I. Cortés-Gutiérrez et al., 2010 Licensee PAGEPress, Italy

European Journal of Histochemistry 2010; 54:e32 doi:10.4081/ejh.2010.e32

trol group. Written informed consent was obtained from all subjects and approval was given by the local Centro de Investigación Biomédica del Noreste (CIBIN) IMSS Ethics Committee.

\section{Identification of human papilloma virus}

HPV detection and genotyping were performed using an Inno-LiPA HPV kit (Microgen Bioproducts, Camberley, Surrey, UK).

\section{Slide preparation}

Cytological specimens from patients were collected with a cytobrush from colposcopically identified koilocytosis areas. The material was submerged in $5 \mathrm{~mL}$ of cold PBS buffer. The samples were brought to the laboratory under cold conditions and were processed within an hour of sampling. A Trypan Blue test was performed on $20 \mu \mathrm{L}$ of cervical epithelial cells to determine the percentage of viable cells for every individual. All samples showed viability $\geq 85 \%$. The cell suspension was mixed with low melting point agarose at $37^{\circ} \mathrm{C}$ to give a fina concentration of $0.7 \%$. The mixture $(15 \mu \mathrm{L})$ was pipetted onto slides pretreated with agarose, covered with glass cover slips (24 mm $\times 24 \mathrm{~mm}$ ) and left at $4^{\circ} \mathrm{C}$ for $5 \mathrm{~min}$.

\section{Detection-fluorescence in situ hybridization}

The cover slips were gently removed to get the slides ready for processing. For DBD-FISH, 
it is important to avoid the slide drying, being the protocol a continuous process. The method basically consists of a protein-depletion procedure followed by treatment with an alkaline solution to produce ssDNA. In this case, for depletion of protein from epithelial cells, slides were treated with a basic solution containing 2 $\mathrm{M} \mathrm{NaCl}, 0.05$ M EDTA, 0.4 M Tris-base and 1\% SDS at $43^{\circ} \mathrm{C}$ for $25 \mathrm{~min}$. Slides were incubated horizontally to avoid chromatin loss. After protein removal, the resultant nucleoids were washed in $0.9 \% \mathrm{NaCl}$ for $10 \mathrm{~min}$. For ssDNA production, protein-depleted slides were incubated in an alkaline unwinding solution (0.03 $\mathrm{M} \mathrm{NaOH}, 1 \mathrm{M} \mathrm{NaCl}$ ) for $2.5 \mathrm{~min}$ at room temperature. After neutralizing with $0.4 \mathrm{M}$ Tris$\mathrm{HCl}$, pH 7.5, for $5 \mathrm{~min}$, nucleoids were washed in TBE ( $89 \mathrm{mM}$ Tris, $89 \mathrm{mM}$ boric acid, $2.5 \mathrm{mM}$ EDTA, $\mathrm{pH}=8.3$ ) buffer for 2 min. For ssDNA stabilization, slides were dehydrated in sequential $70 \%, 90 \%$ and $100 \%$ ethanol baths for 2 min each, and then air-dried.

\section{FISH}

Whole-genome DNA probes were obtained from lymphocyte pellets using a DNA isolation kit for mammalian blood (Roche Diagnostics Corporation, Indianapolis, IN, USA). One microgram from each DNA sample was labeled with digoxigenin-11-dUTP employing a commercial nick-translation kit (Roche Diagnostics Corporation, Indianapolis, IN, USA). The digoxigenin-labeled whole-genome probe was denatured and incubated on slides. After overnight incubation at room temperature, slides were washed twice at room temperature in each of $50 \%$ formamide/ $2 \times \mathrm{SSC}$, pH 7 , for 5 min, and then in $2 \times \mathrm{SSC}, \mathrm{pH} 7$, for $3 \mathrm{~min}$. The hybridized DNA probe was detected with 30 min incubation with fluorescein isothiocyanate-labeled avidin (1:400) (Roche Diagnostics Corporation, Indianapolis, IN, USA). The slides were counterstained with propidium iodide $(1 \mu \mathrm{g} / \mathrm{mL})$ in Vectashield (Vector Laboratories, Burlingame, CA, USA).

\section{Comet assay}

To confirm the results observed with DBDFISH, the alkaline comet assay was performed as described by Singh et al. (1989). ${ }^{13}$ The protein depletion, alkaline unwinding and alkaline treatments were performed as previously described for the DBD-FISH technique. The slides were placed horizontally on an electrophoresis tray, which was filled with fresh alkaline electrophoresis solution (0.03 M $\mathrm{NaOH}, \mathrm{pH} 13)$. Electrophoresis was then conducted on ice with an electric field of $25 \mathrm{~V}$ for $20 \mathrm{~min}$. All of these steps were carried out in a darkroom to prevent interference by additional DNA damage. After electrophoresis, the slides were gently removed from the tray and washed with neutralizing buffer for $5 \mathrm{~min}$. Finally, the slides were washed in distilled $\mathrm{H}_{2} \mathrm{O}$ for 5 min and then dehydrated in a sequential series of $70 \%, 90 \%$ and $100 \%$ ethanol and stained with ethidium bromide.

\section{Image analysis and statistics}

All slides were analyzed using a Digital Image Analysis platform based on a Leica DMLB fluorescence microscope equipped with three lowpass band filters for visualization of green, red and blue fluorescence. Images were acquired with a Leica DF-35 16-bit black and white CCD camera in a 16-bit TIFF format. Image analysis was performed to compare the fluorescence intensities obtained after DBD-FISH. For this purpose, integrated density (ID) (area $\times$ gray scale) and CM/ID (chromatin mass/integrated density) after background subtraction were calculated using the Leica Q-Win image analysis software. After background subtraction, 20 different cells were measured for each individual. The Kruskal- Wallis test was used to investigate any possible difference between ID and CM/ID in different types of cells. A value of $\mathrm{P}<0.05$ was considered significant.

\section{Results and Dicussion}

DBD-FISH performed under the mild alkaline denaturation conditions of protein removal and ssDNA production, as used in this study, was effective for detecting regions of the cervix where normal epithelial cells showed a low density of ALS. However, koilocytes (bi/multinucleated) showed a notable increase in the number of ALS of 50 times and 200 times, respectively (Figure 1). The ID obtained after image analysis allows clear discrimination between the different types of cells (Table 1).

In control women, all cells showed values for ALS density that were similar to normal epithelial cells of patients with CIN 1 (data not shown). These regions represent the background detected after DBD-FISH for this type of cell and could be considered as the constitutive level of ALS.

In fact, the chromatin of the koilocytes tends to be more relaxed and as a result they are more intensely affected by protein depletion than normal cells, producing large haloes of chromatin. The haloes observed in multinucle-

Table 1. Fluorescence analysis (area, intensity, ID, and mass/ID) of koilocytes (binucleate and multinucleate) and normal nuclei of cervical epithelial cells of women with CIN 1 after DBD-FISH.

\begin{tabular}{lcccc} 
Cell type & $\begin{array}{c}\text { Area } \\
(\text { mean } \pm \text { SD })\end{array}$ & $\begin{array}{c}\text { Fluorescence analysis } \\
\text { Intensity } \\
(\text { mean } \pm \text { SD })\end{array}$ & $\begin{array}{c}\text { ID } \\
(\text { mean } \pm \text { SD })\end{array}$ & $\begin{array}{c}\text { CM/ID } \\
(\text { mean } \pm \text { SD })\end{array}$ \\
Normal & $2 \times 10^{3} \pm 3 \times 10^{3}$ & $78 \times 10^{3} \pm 77 \times 10^{3}$ & $3 \times 10^{8} \pm 7 \times 10^{8}$ & $1.5 \mathrm{E}^{5}$ \\
Koilocytes & $18 \times 10^{3} \pm 7 \times 10^{3 *}$ & $864 \times 10^{3} \pm 639 \times 10^{3 *}$ & $173 \times 10^{8} \pm 123 \times 10^{8 *}$ & $9.6 \mathrm{E}^{5 *}$ \\
$\begin{array}{l}\text { Binucleate } \\
\text { Multinucleate }\end{array}$ & $37 \times 10^{3} \pm 11 \times 10^{3 *}$ & $1645 \times 10^{3} \pm 1037 \times 10^{3 *}$ & $624 \times 10^{8} \pm 480 \times 10^{8 *}$ & $16 \mathrm{E}^{5 *}$ \\
\hline
\end{tabular}

$\mathrm{ID}=$ integrated density (area $\mathrm{x}$ fluorescence intensity); $\mathrm{CM}=$ chromatin mass; ${ }^{*}$ Different to control, $\mathrm{P}<0.05$.

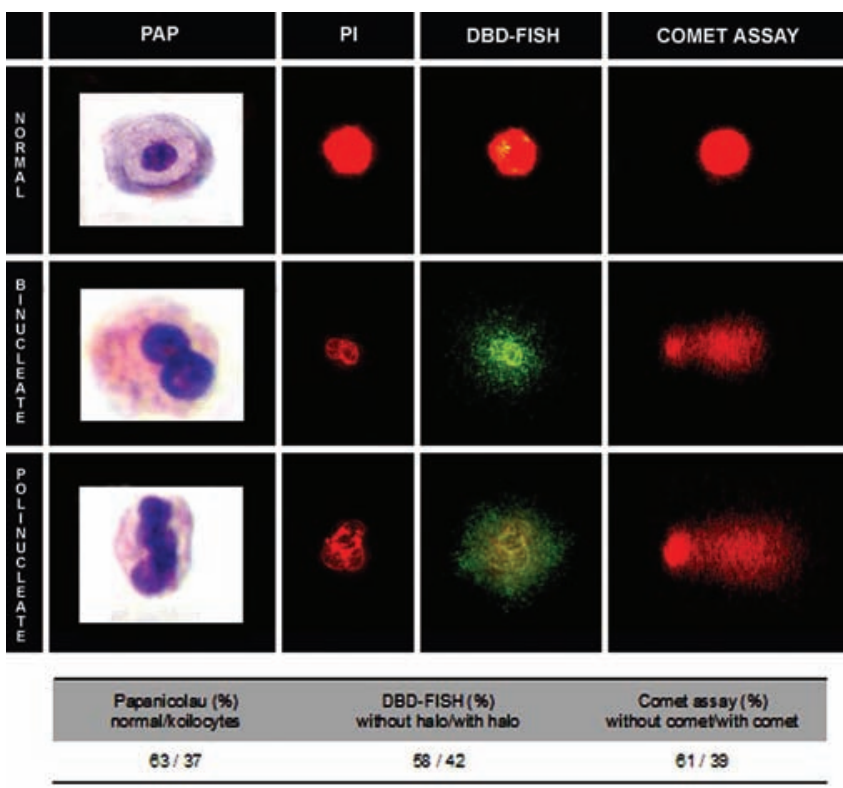

Figure 1. Papanicolaou-stained cervix epithelial cells showing p r o p i d i u m iodide (PI), DBD-FISH, and comet assay of normal cells, binucleate/multinucleate koilocyes, demonstrating the percentage of koilocytes (binucleate and multinucleate) in the Papa nicolaou stain, the halo of hybridization in DBD-FISH, and a comet assay on one specimen with CIN 1. 
Table 2. HPV genotyping in cytological specimens of women with CIN 1.

\begin{tabular}{|c|c|c|c|c|c|c|c|c|c|c|c|c|c|c|}
\hline & & & & & & & V & enot & pes & & & & & \\
\hline Patient & 16 & 18 & 26 & 31 & 33 & 39 & 44 & 51 & 52 & 54 & 68 & 70 & 69-71 & 82 \\
\hline A & $X$ & & & X & $X$ & & $X$ & X & $X$ & $X$ & & & & \\
\hline B & & & X & X & $X$ & & $X$ & & $X$ & X & & & $X$ & \\
\hline $\mathrm{C}$ & $X$ & & & & & & & & & & & & & \\
\hline D & & & $X$ & $X$ & $X$ & & $X$ & & $X$ & $X$ & & & $X$ & \\
\hline E & & & X & & & & & & & & & & & \\
\hline Total & 2 & - & 3 & 3 & 3 & - & 3 & 1 & 3 & 3 & - & - & 2 & - \\
\hline
\end{tabular}

HPV-high risk: 16, 18, 26*, 31, 33, 39, 51, 52, 82. HPV-low risk: 44, 54, 68, 69-71, 70. *Should be considered probably carcinogenic. ${ }^{19}$

ated cells are larger than those observed in binucleated cells (Figure 1). This results in an increase in the surface area as detected by image analysis (Table 1). A Kruskal-Wallis test showed that significant differences are present between all groups when comparisons are performed between the normal cells and koilocytes or between binucleated and multinucleated koilocytes.

The presence of ALS as revealed by DBDFISH was confirmed using a comet assay performed under alkaline conditions (Figure 1). We analyzed the percentage of koilocytes (bi/multinucleate), the halo of hybridization in DBD-FISH and the results of a comet assay in one specimen with CIN 1 . The results obtained showed no significant differences among the results of these tests (Figure 1).

ALS may be a consequence of DNA abasic sites and/or deoxyribose damage. Nevertheless, in cells unexposed to DNA-damaging agents, ALS should not be a consequence of certain DNA lesions, but mainly a constitutive feature of certain normal chromatin structures. ${ }^{14}$ Although the molecular biology and significance of constitutive ALS are not well understood, some observations support that these genomic regions escape the normal DNA configuration and may be transient structural features of the cells. The role of constitutive ALS in chromatin packaging could be exemplified in human spermatozoa. Unlike leucocytes, certain repetitive satellite DNA sequences and the whole genome of the spermatozoa are extremely alkali sensitive, showing signals using a whole-genome probe under DBD that is 12.7 times more intense than in peripheral blood leucocytes. ${ }^{14}$ Constitutive ALS may be a consequence of torsional stress of DNA loops associated with tight chromatin packing. ${ }^{15}$ Even under homeostatic cell conditions, the presence of ALS may vary among cell types in mammalian species. ${ }^{8,9,16,17}$ The presence of ALS has also been demonstrated in certain sequence areas from insect cells. ${ }^{18}$

The results of HPV detection-genotyping are presented in Table 2. Among the five patients who presented with HPV infection, three had multiple infections with both high-risk and low-risk types of HPV (patients A, B, and D), and two (C and E) had infection with only high-risk HPV types (types 16 and 26, respectively). ${ }^{19}$ All control women were HPV negative.

In this context, one possible mechanism that could explain the increase of ALS in koilocytes is HPV infection. The presence of ALS in the genome appears to be a structural feature of chromatin. The induction of chromatin changes is an emerging topic in the study of viral tumorigenesis in humans, not only in relation to high-risk HPV types ${ }^{20}$ but also to hepatitis B virus, ${ }^{21}$ Kaposi's sarcoma herpesvirus, ${ }^{22}$ and human T-cell leukemia virus type 1 (HTLV-1). ${ }^{23}$

Several studies have reported changes in chromatin organization during HPV infection. The association of DNA-binding proteins with the nuclear matrix may be related to a functional role of this subcellular structure in chromatin organization and gene regulation. ${ }^{24}$ It is generally accepted that the state of chromatin can have a major impact on gene expression. DNA that is densely packaged into nucleosomes is inaccessible to the transcriptional machinery, and expression of a particular gene is therefore contingent on such modifications of the chromatin as histone acetylation, ATPdependent SWI/SNF, and SNF5. ${ }^{25}$

From a clinical perspective, we suggest that ALS may serve as a novel tool to predict the progression of CIN. Preliminary results in our laboratory revelead a correlation between cervical lesion grade and ALS levels.

Our preliminary results demonstrate that the presence of ALS could be an indicator of chromatin changes in koilocytosis caused by HPV infection. However, further studies with different groups of HPV types, CIN status and disease severity are needed.

\section{References}

1. Vooijs GP. Benign proliferative reaction, intraepithelial neoplasia, and invasive cancer of the uterine cervix. In: Bibbo M, ed. Comprehensive cytopathology. Phila- delphia, PA: WB Saunders, 1997: 161-230.

2. Herrington $S$. The pathogenesis of cervical neoplasia. In: Gray W, McKee GT, ed. Diagnostic cytopathology. London, England: Churchill Livingstone, 2003:70753.

3. Cho NH, Kang S, Hong S, Jeong GB, Choi IW, Choi HJ et al. Multinucleation of koilocytes is actually multilobation. Int $\mathrm{J}$ Gynecol Cancer 2006;16:686-9.

4. Krawczyk E, Suprynowicz FA, Liu X, Dai Y, Hartmann DP, Hanover J et al. Koilocytosis: a cooperative interaction between the human papillomavirus E5 and E6 oncoproteins. Am J Pathol 2008;173:682-8.

5. Fernández JL, Goyanes V, Ramiro-Diaz J, Gosálvez J. Application of FISH for in situ detection and quantification of DNA breakage. Cytogenet Cell Genet 1998;82: 251-6.

6. Fernández JL, Gosálvez J. Application of FISH to detect DNA damage: DNA breakage detection-FISH (DBD-FISH). In: Methods in Molecular Biology. ed. V. Didenko). Totowa, NJ: Humana Press Inc; 2002:203-16.

7. Fernández JL, Goyanes V, Gosálvez J. DNA Breakage Detection-FISH (DBD-FISH). In: FISH Technology. ed. B. W. Rautenstrauss \& T. Liehr). Springer-Verlag, Heidelberg; 2002:282-90.

8. Cortés-Gutiérrez EI, Dávila-Rodríguez MI, López-Fernández C, Fernández JL, Gosálvez J. Alkali-labile sites in sperm cells from Sus and Ovis species. Int $\mathrm{J}$ Androl 2008;31:354-63.

9. Fernández JL, Vazquez-Gundin F, Rivero MT, Goyanes V, Gosálvez J. Evidence of abundant constitutive alkali-labile sites in human 5 bp classical satellite DNA loci by DBD-FISH. Mutat Res 2001;473:163-8.

10. Schneider A, Meinhardt G, De Villiers EM, Gissmann L. Sensitivity of thecytologic diagnosis of cervical condyloma in comparison with HPV-DNA hybridization studies. Diagn Cytopathol 1987;3:250-5

11. Kruman, R.J, Solomon D. ed. Bethesda System for reporting cervical/vaginal cytologic diagnosis. Springer New York,1994.

12. Creasman WT. New gynecologic cancer staining. Obstet Gynecol 1990;75:287-8.

13. Singh NP, McCoy MT, Tice RR, Schneider EL. A simple technique for quantitation of low levels of DNA damage in individual cells. Exp Cell Res 1988;175:184-91.

14. Muriel L, Segrelles E, Goyanes V, Gosálvez J, Fernández JL. Structure of human sperm DNA and background damage, analysed by in situ enzymatic treatment and digital image analysis. Mol Hum Reprod 2004;10:203-9.

15. Darzynkiewicz Z, Huang X, Okafuji M. Detection of DNA strand breaks by flow 
and laser scanning cytometry in studies of apoptosis and cell proliferation (DNA replication). Methods Mol Biol 2006;314: 81-93.

16. Rivero MT, Vazquez-Gundin F, Goyanes V, Campos A, Blasco M, Gosálvez J et al. High frequency of constitutive alkali-labile sites in mouse major satellite DNA, detected by DNA breakage detection-fluorescence in situ hybridization. Mutat Res 2001;483:4350.

17. Rivero MT, Mosquera A, Goyanes V, Slijepcevic P, Fernández JL. Differences in repair profiles of interstitial telomeric sites between normal and DNA doublestrand ALS in mammalian sperm break repair deficient Chinese hamster cells. Exp Cell Res 2004;295:161-72.

18. López-Fernández C, Arroyo F, Fernández JL, Gosálvez J. Interstitial telomeric sequence blocks in constitutive pericen- tromeric heterochromatin from Pyrgomorpha conica (Orthoptera) are enriched in constitutive alkali-labile sites. Mutat Res 2006;599:36-44.

19. Muñoz N, Bosch FX, de Sanjosé S, Herrero $\mathrm{R}$, Castellsagué X, Shah KV et al. Epidemiologic classification of human papillomavirus types associated with cervical cancer. N Engl J Med 2003;348:51827.

20. Wilczynski SP, Walker J, Liao SY, Bergen S, Berman M. Adenocarcinoma of the cervix associated with human papillomavirus. Cancer 1988; 62:1331-6.

21. Ozkal P, IIgin-Ruhi H, Akdogan M, Elhan AH, Kacar S, Sasmaz N. The genotoxic effects of hepatitis B virus to host DNA. Mutagenesis 2005;20:147-50.

22. Pan H, Zhou F, Gao SJ. Kaposi's sarcomaassociated herpesvirus induction of chromosome instability in primary human endothelial cells. Cancer Res 2004;64: 4064-8.

23. Majone F, Luisetto R, Zamboni D, Iwanaga $\mathrm{Y}$, Jeang KT. Ku protein as a potential human T-cell leukemia virus type 1 (HTLV1) Tax target in clastogenic chromosomal instability of mammalian cells. Retrovirology 2005;2:45.

24. van Wiijen AJ, Bidwell JP, Fey EG, Penman S, Lian JB, Stein JL et al. Nuclear matrix association of multiple sequence-specific DNA binding activities related to SP-1, ATF, CCAAT, C/EBP, 0CT-1, and AP-1. Biochemistry 1993;32:8397-402.

25. del Mar Peña L, Laimins LA. Differentiation-dependent chromatin rearrangement coincides with activation of human papillomavirus type 31 late gene expression. J Virol 2001;75:10005-13. 